Adv. Geosci., 14, 3-11, 2008

www.adv-geosci.net/14/3/2008/

(C) Author(s) 2008. This work is licensed

under a Creative Commons License.

\title{
The critical role of volcano monitoring in risk reduction
}

\author{
R. I. Tilling \\ Scientist Emeritus, Volcano Hazards Team, U.S. Geological Survey, Menlo Park, California 94025-3591, USA
}

Received: 1 September 2007 - Revised: 15 September 2007 - Accepted: 19 September 2007 - Published: 2 January 2008

\begin{abstract}
Data from volcano-monitoring studies constitute the only scientifically valid basis for short-term forecasts of a future eruption, or of possible changes during an ongoing eruption. Thus, in any effective hazards-mitigation program, a basic strategy in reducing volcano risk is the initiation or augmentation of volcano monitoring at historically active volcanoes and also at geologically young, but presently dormant, volcanoes with potential for reactivation. Beginning with the 1980s, substantial progress in volcano-monitoring techniques and networks - ground-based as well space-based - has been achieved. Although some geochemical monitoring techniques (e.g., remote measurement of volcanic gas emissions) are being increasingly applied and show considerable promise, seismic and geodetic methods to date remain the techniques of choice and are the most widely used. Availability of comprehensive volcano-monitoring data was a decisive factor in the successful scientific and governmental responses to the reawakening of Mount St. Helens (Washington, USA) in 1980 and, more recently, to the powerful explosive eruptions at Mount Pinatubo (Luzon, Philippines) in 1991. However, even with the ever-improving state-ofthe-art in volcano monitoring and predictive capability, the Mount St. Helens and Pinatubo case histories unfortunately still represent the exceptions, rather than the rule, in successfully forecasting the most likely outcome of volcano unrest.
\end{abstract}

\section{Introduction}

Since the 17th century, volcanic disasters have killed more than 300000 people and caused property damage and economic loss in excess of many hundreds of millions dollars (Tilling, 1989a, 2005). The risk to humankind posed by volcano hazards - those affecting people on the ground as well

Correspondence to: R. I. Tilling

(rtilling@usgs.gov) as those from encounters between aircraft and drifting volcanic clouds from energetic explosive eruptions - will inexorably increase because: 1) the number of volcanoes active per year in the world varies little, ranging between 50 and 70 on average (Simkin and Siebert, 1994); 2) global population continues to grow exponentially in the 21st century; and 3 ) air traffic (passenger and cargo) worldwide is increasing sharply (Fig. 1). Fortunately however, with the emergence of modern volcanology in the 20th century, the risk from volcanic hazards can be anticipated, assessed, and mitigated by scientific studies and timely governmental actions.

This paper derives from a keynote presentation given at the Second Alexander von Humboldt Conference in Lima, Perú, in March 2007 (Tilling, 2007a). An exhaustive treatment of volcano monitoring is beyond the scope of this brief paper, which instead provides an overview of the rationale and the critical need for monitoring potentially hazardous volcanoes. For a detailed, comprehensive technical understanding of volcano-monitoring studies and their applications, the interested reader is referred to recent summary papers and references cited therein (e.g., Tilling, 1995; Scarpa and Tilling, 1996; McNutt, 2000a, b; Chouet, 2004; Dzurisin, 2006; Chouet, $2007^{1}$ ).

\section{Volcano monitoring and risk reduction}

Available data for historical eruptions clearly indicate that they are almost always preceded and accompanied by "volcanic unrest," as manifested by physical and (or) chemical changes in the state of the volcano and (or) its associated hydrothermal system. Such precursory phenomena (e.g., seismic, geodetic, gravity, magnetic, geoelectrical, gas emission), which provide early warning of possible impending eruption and attendant volcano-related hazards, are readily

\footnotetext{
${ }^{1}$ Chouet, B.:Nonlinear processes in volcanoes, Encyclopedia of Complexity and System Science, submitted August 2007.
}

Published by Copernicus Publications on behalf of the European Geosciences Union. 


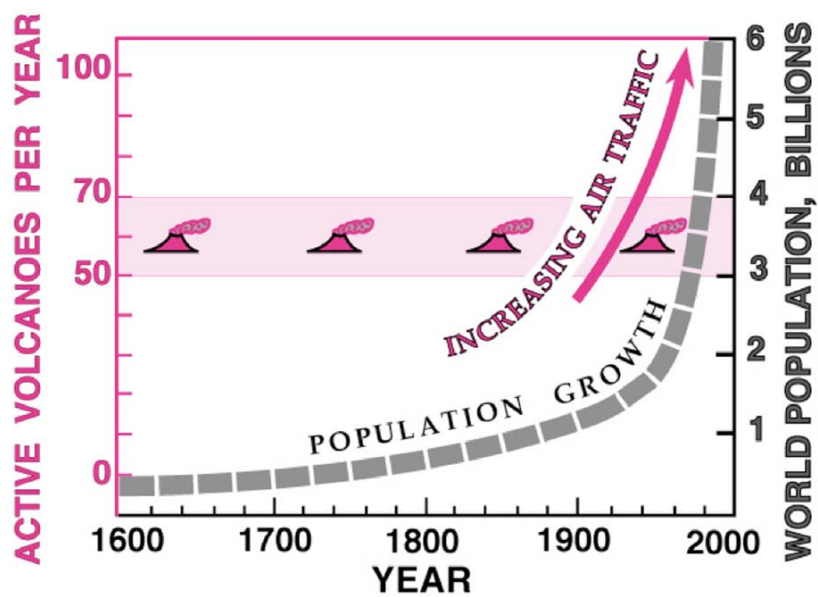

Fig. 1. Schematic showing that, while the number of volcanoes active per year (bracketed by pink band) varies only slightly on average worldwide (50-70 according to Simkin and Siebert (1994)), the risk from volcano hazards grows inexorably because of continuing growth in world population and sharply increasing air traffic (from Tilling, 2003, Fig. 1).

detectable by volcano monitoring - the systematic collection, analysis, and interpretation of visual observations and instrumental measurements at volcanoes before, during, and after eruptive activity.

\subsection{Why volcano monitoring?}

From a purely scientific perspective, volcano monitoring generates the primary data needed by volcanologists and other researchers to investigate and deduce the dynamics of active volcanic systems and associated eruptive and geothermal processes. However, in addition to satisfying scientific curiosity and advancing volcanology, volcano-monitoring studies also play a direct and societally relevant role in reducing volcano risk. Geologic mapping and other geoscience investigations are prerequisites to establish the past behavior of a volcano, particularly its eruptive style (explosive, nonexplosive, continuous, episodic, etc.) and the ages, areal distribution, and volumes of deposits from previous eruptions. Such studies provide the data for long-term forecasts (centuries to decades) of possible future activity and preparation of hazards assessments and hazards-zonation maps. In contrast, volcano-monitoring data document the present-day behavior of a volcano, which, when combined with knowledge of past eruptive behavior, allows anticipation of the volcano's possible future behavior. Especially important for risk reduction, data from volcano monitoring constitute the only scientific basis for short-term forecasts (years to days) of a future eruption, or of possible changes during an ongoing eruption. Hazards assessments, volcano monitoring, and effective communications among scientists, civil authorities, and the general public comprise the core elements of any successful program to reduce risk from volcano hazards (Fig. 2).

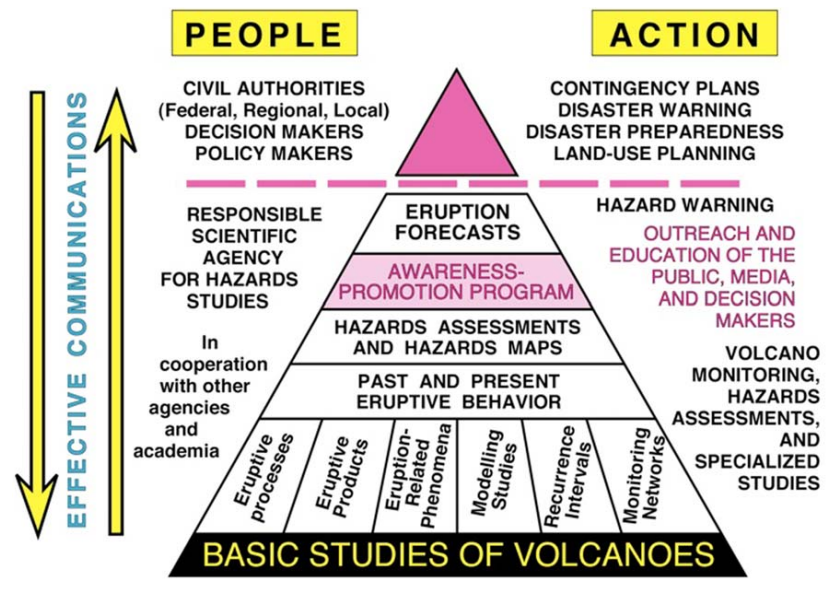

Fig. 2. Diagram of the essential elements of an effective program to reduce volcano risk. Hazards assessments, hazards-zonation maps, and volcano-monitoring studies constitute important components in the process beginning with basic studies of volcanoes. The apex is separated from the rest of the triangle to emphasize that scientists, while providing the best possible scientific information and advice, do not have knowledge of other key factors (e.g., socioeconomic, cultural, political) and authority to make decisions regarding land-use planning, disaster preparedness and warning, contingency plans, and other mitigative measures, including possible evacuation (modified from Tilling, 1989b, Fig. 1.3).

\subsection{Importance of pre-eruption baseline monitoring data}

When a volcano - especially one that heretofore has been quiescent or typically only weakly active - begins to exhibit noticeable or heightened unrest, civil authorities and local inhabitants, quite rightly, have reason to become concerned about the possibility of renewed or increased activity and associated hazards. If this unrest persists and escalates, the paramount question for scientists and public officials in dealing with the developing volcanic crisis is: What is the most likely outcome of the escalating unrest? (Fig. 3a). Of course, it is impossible even to attempt to answer this question scientifically without information from volcano-monitoring data. But even with monitoring data, the outcomes of volcanic unrest still can be highly variable (Fig. $3 b$ ) because of several complicating factors: 1) the character and duration of the unrest can be highly irregular with no definitive pattern; 2) the overall build-up, though irregular, suggests that renewed eruption or stronger-than-normal activity could be possible, perhaps even imminent; and 3) scientists cannot guarantee that eruption will NOT occur. In any case, the public officials are faced with a rapidly approaching and narrow "decision window" whether or not to take action to manage the volcanic crisis.

Ideally, volcano monitoring of active and potentially active volcanoes should be conducted on a real-time or nearreal-time basis. Also, it is important to acquire pre-eruption 


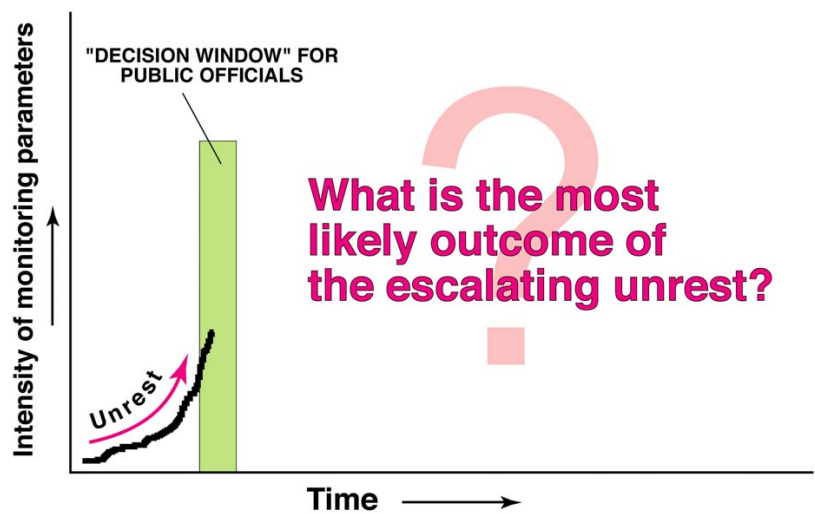

Fig. 3a. The "decision window" confronting public officials after the onset of a volcanic crisis; in general, the most likely outcome of escalating volcano unrest is unknown (see text) (base diagram courtesy of C. Dan Miller, USGS).

monitoring data for a given volcano, to determine its typical range of seasonal or other transient departures from its normal or "baseline" behavior. In general, the longer the time span of the baseline monitoring data, the more diagnostic and useful are the data in making robust, reliable short-term forecasts. A good example of long-term baseline monitoring data is represented by ground-deformation measurements for the summit of Kilauea Volcano, Hawaii, (Fig. 4). Volcanomonitoring studies are most conveniently and efficiently conducted by scientists at permanent academic or government facilities or institutions (e.g., "volcano observatories").

However, if economic and scientific resources preclude the operation of a permanent volcano observatory, the rapid dispatch of a "mobile volcano observatory" (Murray et al., 1996) and scientific team to respond to a volcanic crisis has proven to be successful, such as to the 1991 eruption of Mount Pinatubo, Philippines (see below).

With about 550 volcanoes in the world - mostly in the developing regions - that have erupted historically one or more times, clearly there are not enough volcano observatories, scientists, and equipment to adequately monitor them all. While this situation is especially dire for the developing countries, it also poses a problem for developed countries. Thus, to best utilize the available resources, it is necessary to make a comprehensive evaluation of the threat posed by each volcano, its current level of ground-based volcano monitoring (if any), populations at risk from potential hazards, and other factors to establish priorities in acquiring or improving baseline monitoring data. Recently, the U.S. Geological Survey has undertaken such an assessment of volcanic threat and monitoring capabilities in the United States, to emphasize the need to develop "... a proactive, fully integrated, national-scale monitoring effort that ensures the most threatening volcanoes in the United States are properly monitored in advance of the onset of unrest (italics added) and at levels

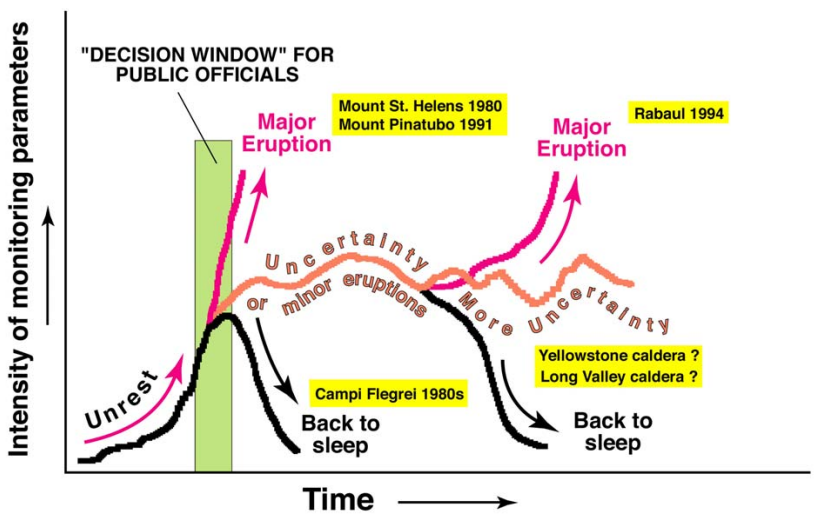

Fig. 3b. Some examples of the actual outcomes of heightened volcano unrest at selected volcanoes (see text for discussion).

commensurate with the threats posed." (Ewert et al., 2005, p. 3).

2.3 Selected examples of volcano-monitoring data and outcomes of volcano unrest

As schematically illustrated in Fig. 3b, several recent episodes of volcano unrest have resulted in quite different outcomes, some of which are discussed herein. For the reawakening and eruption of Mount St. Helens Volcano, Washington, in 1980, after a 123 -year period of quiescence, systematic pre-eruption volcano-monitoring studies contributed materially to successful risk-reduction measures taken by State and Federal governmental officials prior to its climactic eruption on 18 May 1980, which caused the worst volcanic disaster in the history of the United States. In this case, the well-monitored volcano unrest only lasted for a few months before culminating in a major eruption on the 18 May (see Lipman and Mullineaux (1981) for a detailed summary).

Similarly, the 1991 eruption of Mount Pinatubo (Luzon, Philippines) represents another example of simple and relatively short progression from precursory activity to fullblown eruption (Newhall and Punongbayan, 1996). Reclassified from an "inactive" to "active" volcano in 1987 (based on a single carbon-14 date), Pinatubo began to exhibit increased fumarolic activity in early March of 1991, followed by felt precursory earthquakes a few weeks later and then phreatic explosions beginning on 2 April. However, adequate volcano monitoring of the rapidly escalating unrest at Pinatubo (previously little studied) did not commence until late April, when a team of scientists from the U.S. Geological Survey (USGS) - under the auspices of the Volcano Disaster Assistance Program (Ewert et al., 1997) - joined colleagues of the Philippine Institute of Volcanology and Seismology (PHIVOLCS) to hurriedly establish a "mobile volcano observatory" (Murray et al., 1996) and prepare a hazards-zonation map, under difficult and stressful conditions of an escalating volcanic crisis (Fig. 5). 
Summit Tilt of Kìlauea $1956-1999$

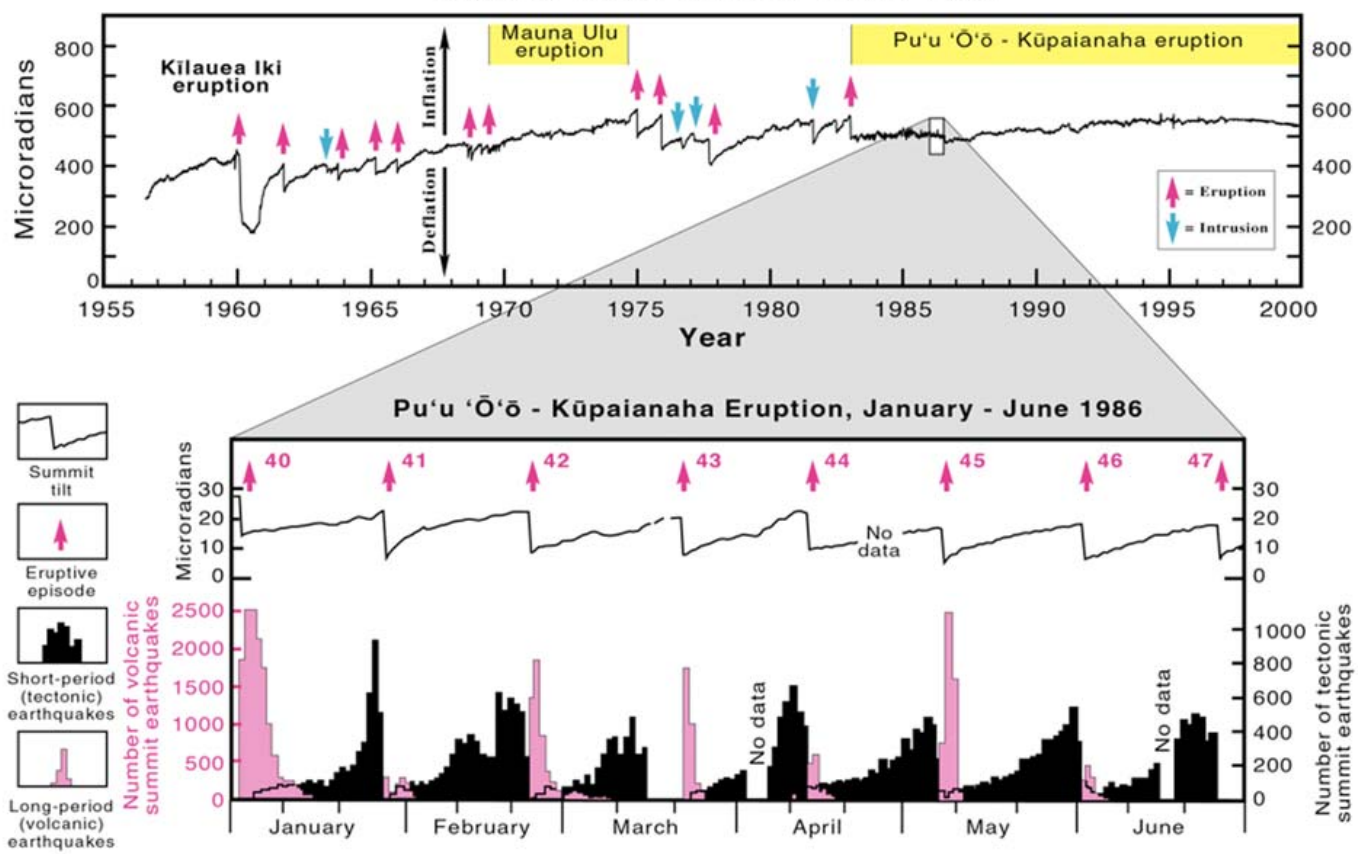

Fig. 4. Example of long-term "baseline" monitoring data: Variations in ground deformation at the summit of Kilauea Volcano, Hawaii, for the period 1956-1999, as recorded by a continuously recording tiltmeter maintained by the Hawaiian Volcano Observatory of the U.S. Geological Survey. Note that each eruption or intrusion event is preceded by gradual inflation and terminated by abrupt deflation; in general, the larger the event, the greater the change in tilt (modified/updated from Tilling et al., 1987).

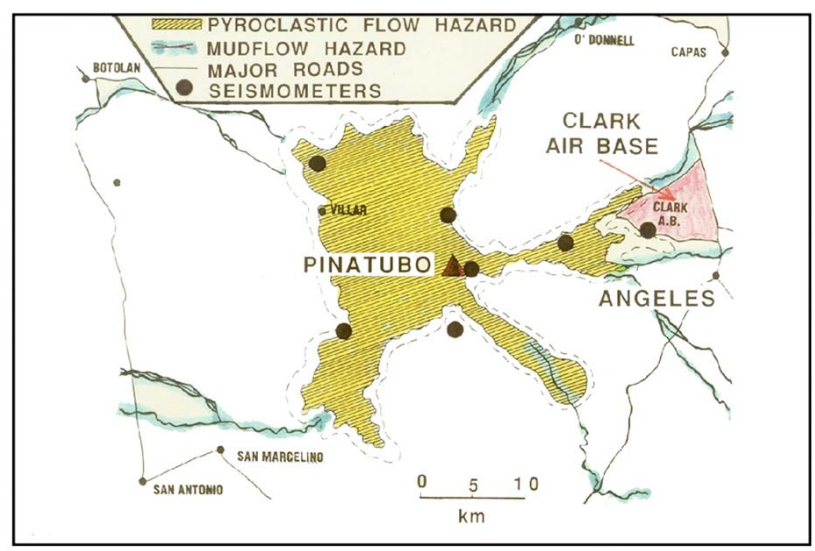

Fig. 5. Sketch of the volcanic-hazards map for Mount Pinatubo, Philippines; locations of seismometers are shown by solid circles. The installation of the seismic network and preparation of the hazards map had to be accomplished very quickly because of the rapidly evolving volcanic crisis (sketch from Christopher G. Newhall, USGS).

Systematic monitoring of seismicity and emission of sulfur dioxide $\left(\mathrm{SO}_{2}\right)$ became operational by early May (Fig. 6). The emission of $\mathrm{SO}_{2}$ increased through most of May but then began to decline sharply after 28 May, interpreted by the PHILVOLCS-USGS scientific team to indicate the rise of magma high into the conduit, ultimately resulting in the emergence of a lava dome observed on 7 June (Fig. 6a). A few days before the dome extrusion, the total seismic energy release also exhibited a notable increase beginning on 1 June (Fig. 6b). The foci of seismic events during the period 6 May to 12 June revealed a significant migration, shifting from a diffuse cluster located about $5 \mathrm{~km}$ NNW beneath the steaming vents to a tighter concentration located directly beneath these vents in the summit area (see Harlow et al., 1996. Figs. 4, 7, and 9). Moreover, long-period (LP) seismicity and seismic-energy release, further increased preceding the onset of plinian eruptions on 12 June (White, 1996; Harlow et al., 1996).

Collectively, the quickly collected volcano-monitoring data, combined with visual observations of the initiation and increased frequency of eruption columns with heights $>15 \mathrm{~km}$ beginning on 12 June, were pivotal in convincing the scientists to recommend to the Commandant of the U.S. Clark Air Base and the mayors of Philippines population centers to order major evacuations. Three days later, the Pinatubo's climactic eruption occurred on 15 June - the most voluminous eruption in the world since the 1912 eruption of Novarupta (Alaska, USA). The timely evacuation of people and expensive but moveable property (e.g., aircraft, vehicles, equipment, computers, household belongings) by military 

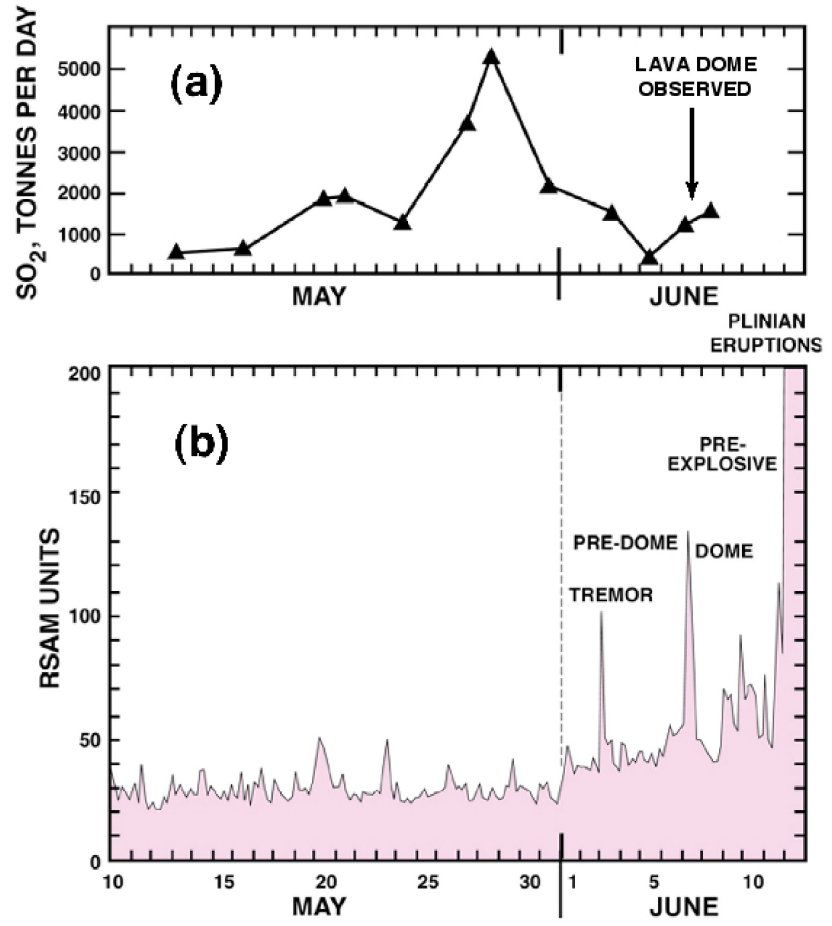

Fig. 6. (a) Gas monitoring of the output of sulfur dioxide at Mount Pinatubo as the volcano built to major magmatic eruption (data source: Daag et al., 1996). (b) Seismic monitoring at Mount Pinatubo by a 7-station network. Total seismic energy release, expressed as RSAM units (Real-time Seismic Amplitude Measurement), began to increase sharply as magma ascended high into the conduit (data source: Harlow et al., 1996).

and civilian officials - prompted by the forecast and recommendations made by PHIVOLCS-USGS scientists based on monitoring data - saved many thousands of lives and hundreds of millions of dollars in economic loss (Ewert et al., 1997).

The 1980 Mount St. Helens and the 1991 Pinatubo case histories arguably represent the simplest scenario of possible outcomes of volcano unrest: pre-eruption unrest of short duration (only several months) culminating in eruption. However, most other recent episodes of unrest involve complex or uncertain outcomes (Fig. 3b). For example, the well-monitored 1983-1985 volcanic crisis at Rabaul Caldera (Papua New Guinea), involving intense seismicity and $>1 \mathrm{~m}$ of uplift (McKee et al., 1985; Mori and McKee, 1987; Mori et al., 1989), prompted government officials to issue a "Stage-2 Alert" (Fig. 7), stating that eruption could occur within weeks. But the forecasted eruption failed to occur, and the seismicity subsided abruptly (Fig. 7) and returned to a normal level for about the next ten years. Predictably, the general public viewed this unexpected and abrupt cessation of the 1983-1985 volcano unrest as a "false alarm," and both the scientists and officials lost credibility. However, the

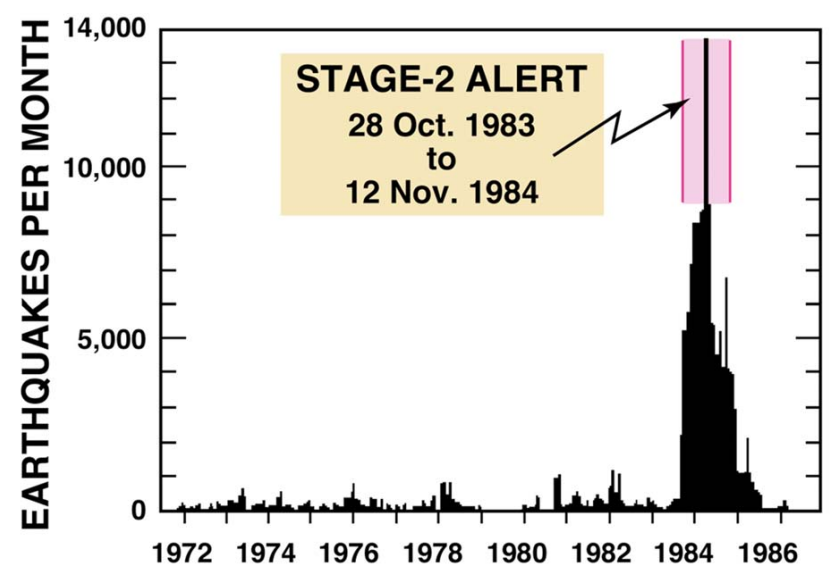

Fig. 7. Seismic monitoring for Rabaul Caldera, Papua New Guinea, 1972-1986; the number of earthquakes increased dramatically during the 1983-1985 volcanic crisis but did not culminate in eruption (see text) (modified from McKee et al., 1985).

Rabaul case history ultimately had a positive outcome influenced by the 1983-1985 crisis, which greatly enhanced official and public awareness of potential volcano hazards. On 19 September 1994, following only $27 \mathrm{~h}$ of precursory seismicity, Rabaul erupted suddenly (Blong and McKee, 1995). Yet, even though the eruption was highly destructive, devastating nearly all of Rabaul city, only 5 people were killed, because the local inhabitants had not forgotten the lessons (e.g., public education about volcano hazards, exercises of contingency plans, practice evacuations) learned a decade earlier.

Also during the period 1983-1984, Campi Flegrei Caldera (near Naples, Italy) underwent strong volcano unrest, expressed by increased seismicity and substantial ground uplift. Similar to the case for Rabaul Caldera, the escalating unrest peaked in 1985 and then began to subside gradually during the ensuing years (Fig. 8a), suggesting an outcome whereby the restless volcano returns to sleep (Fig. 3b). However, a recent study by Troise et al. (2007) shows that the post1985 trend of gradual ground subsidence reversed in October 2005, since which time Campi Flegrei has been exhibiting renewed uplift of a few centimeters (Fig. 8b). Historical observations (of Serapeo Market, Pozzuoli) and modern volcanomonitoring data for Campi Flegrei demonstrate measurable - at times large-scale - deformation of the caldera on a time scale varying from centuries to years (Fig. 8b). Yet, over the past 2000-plus years, only one episode of volcano unrest at Campi Flegrei culminated in eruption, namely at Monte Nuovo in 1538 (De Vito et al., 1987).

In recent decades, volcano unrest at two other caldera systems in the western United States - Long Valley Caldera (California) and Yellowstone Caldera (Wyoming-Montana) - also have been closely tracked by ground-based as well as space-based volcano-monitoring techniques (see, for example, Battagalia et al., 2003; Hill, 2006; Waite and Smith, 


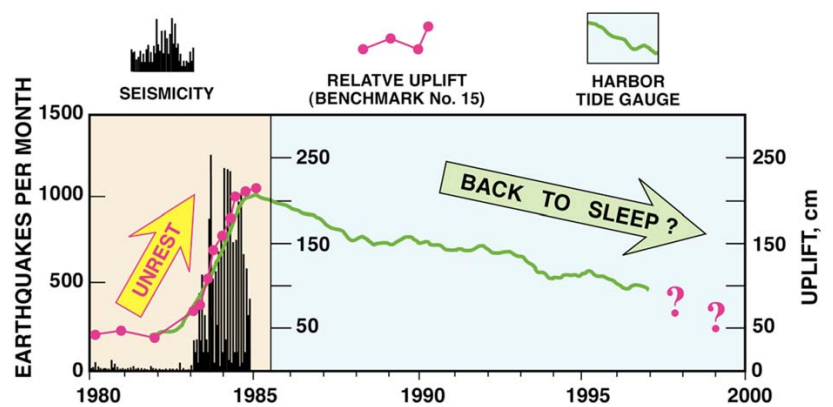

Fig. 8a. Volcano unrest at Campi Flegrei Caldera, Italy, during the period 1983-1985, as expressed by seismicity and ground uplift. This unrest peaked by 1985 , followed by gradual subsidence through 2000, suggesting that the volcano was returning to sleep (data sources: Berrino et al., 1984; De Natale et al., 2001; Osservatorio Vesuviano, 2007).
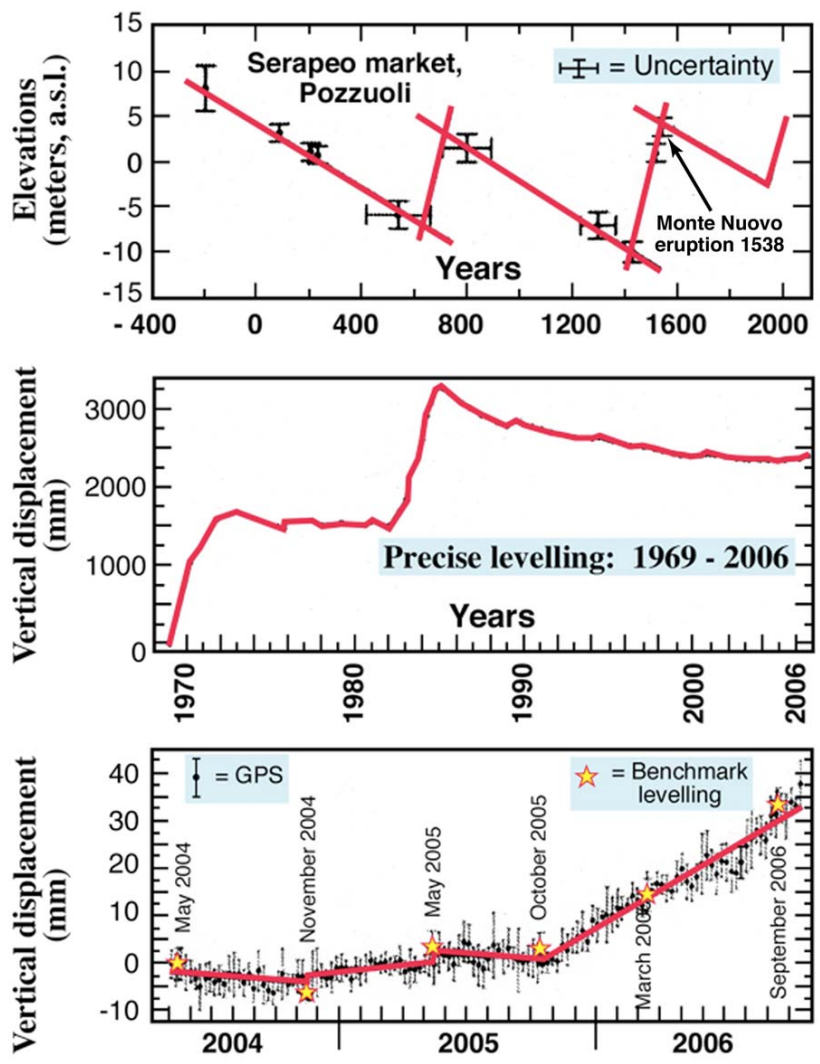

Fig. 8b. Vertical displacements measured at Campi Flegrei Caldera at time scales varying from centuries to years (see text for discussion). Precise-levelling and GPS monitoring data indicate a reversal of the post-1985 subsidence trend in October 2005 and the beginning of another trend of gradual ground uplift (data source: Troise et al., 2007).

2002; Wicks et al., 2006). Figure 9 is an Interferometric Synthetic Aperture Radar (InSAR) image illustrating the uplift at Yellowstone Caldera during the period 1996-2000.

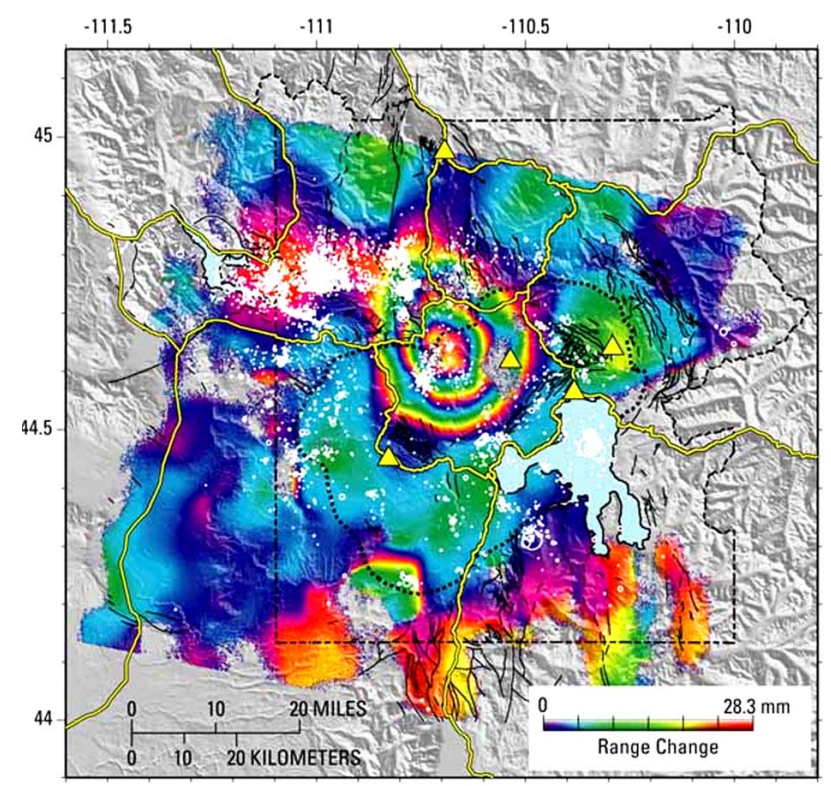

Fig. 9. An example the increasing use of monitoring of "space geodesy" techniques: ground deformation monitored by InSAR at Yellowstone Caldera, Wyoming-Montana, for uplift during the period 1996-2000. Each full spectrum of color fringes (from purple to red) represents $\sim 28 \mathrm{~mm}$. White dots and circles show seismicity during the same time period, yellow triangles are selected continuous GPS monuments, and the dotted black line delimits the caldera boundary (InSAR interferogram courtesy of Charles Wicks, USGS).

While the level and intensity of unrest (uplift and subsidence) at both these calderas have waxed and waned during the monitoring interval, the data collected to date do not hint of possible eruptive activity any time soon.

\subsection{The need for refined eruption forecasts}

The case histories for Rabaul, Campi Flegrei, Yellowstone and Long Valley caldera systems, as well as many (most?) other monitored volcanoes in the world, represent serious challenges for volcanologists in anticipating (1) the most likely outcome of the onset of unrest at long-quiescent volcanoes or (2) the eventual possible culmination in eruption of long-duration, low- to moderate-level ongoing unrest. As evidenced by the scenarios in Figure $3 \mathrm{~b}$ and the preceding discussion, however, precise forecasts of eruption, tightly bracketed in time, still elude volcanologists, even with adequate volcano monitoring. This inability of scientists not being able to give a definitive answer to the question whether escalating unrest will culminate has unfortunate consequences. Obviously, the making of an unfulfilled forecast (e.g., as for Rabaul in the 1980s) results in criticism of a "false alarm" and loss of credibility of scientists and officials alike. However, if progress is to be made in the reduction of volcano risk, scientists have a societal obligation to make the best- 
possible forecast they can within the constraints of available knowledge. By the same token, emergency-management officials and the general public must be prepared to accept the consequences and socio-economic costs of occasional, unavoidable "false alarms." Perhaps Banks et al. (1989, p. 78) were foreseeing the Rabaul case history when they wrote: “... False alarms themselves can provide, through objective assessment of the scientific and public response to a volcanic crisis that ended without eruption, valuable lessons useful... for the next crisis, which could culminate in an eruption (italics added)." In any case, what is critical is that longterm acquisition of monitoring data will expand the databases needed for analyzing and interpreting any future changes in the state of volcano that depart significantly from the variation in baseline behavior. Equally important, however, it is also imperative to develop more robust techniques for the collection and analysis of monitoring data, ideally in real- or near-real time.

In recent decades, substantial advances have been made in volcano-monitoring systems - ground- and spaced-based - and in the acquisition, processing, and interpretation of all types of monitoring data, geochemical and geophysical. Particularly promising are recent quantitative studies in volcano seismology utilizing arrays of broadband instruments. For example, real-time monitoring and analysis of VeryLong-Period (VLP) signals of seismic sources at Stromboli Volcano are currently being conducted by the Osservatorio Vesuviano (e.g., Auger et al., 2006). From experience worldwide, nearly all eruptions are preceded and accompanied by VLP and Long-Period (LP) seismicity. Other specific examples include the quantitative analysis and interpretation of VLP and LP seismic signatures to decipher the magmatic-hydrothermal interactions operative at Kilauea Volcano (Chouet, 2007) and at Mount St. Helens Volcano (Waite et al., 2007). Such studies, combined with data from other monitoring techniques (e.g., geochemical, geodetic, remote sensing) yield a more diagnostic understanding of the interplay between magmatic and associated hydrothermal processes than drive volcanic systems. Worldwide experience also indicates that the optimum volcano-monitoring approach is one that employs a combination of techniques rather than reliance on any single one. An improved understanding of volcano dynamics makes possible more reliable and precise eruption forecasts, which in turn should furnish volcanologists possible criteria and tools in determining which of the various paths shown in Fig. $3 b$ is the most likely outcome of evolving unrest. Most volcanologists are convinced that, if a volcano is monitored extensively in realor near-real time by well-deployed instrumental networks, it should be possible to make much better forecasts of the outcomes of volcano unrest.

\section{Concluding remarks}

In this brief paper, I have emphasized the critical importance of volcano monitoring in reducing the risk posed by volcano hazards, for the simple and basic reason that volcanomonitoring data provide the only scientifically valid basis for making short-term eruption forecasts. Reliable and precise forecasts allow civil authorities to prepare contingency plans, to issue early warnings, and to take timely decisions and mitigative countermeasures, including evacuation if necessary, to protect the populations at risk. In practical terms, when a volcanic crisis develops and governmental authorities must take action, the availability of volcano-monitoring data - especially if long term and comprehensive - effectively expands the timeframe of the "decision window" (Fig. 3) public officials face. Having the widest possible "decision window," officials in turn can make better-informed warnings and decisions to provide greater public safety. With more hazardous volcanoes being monitored in real time, improvements in volcano-monitoring methodologies and technologies, and quantitative data analysis and interpretation, the prospects are excellent for volcano monitoring to be increasingly effective in reducing the risks from volcano hazards.

However, some words of caution are necessary in conclusion. Volcano-monitoring data alone - no matter how complete, timely, and correctly interpreted - cannot automatically guarantee successful outcomes of future volcanic crises, because risk reduction is predominantly influenced by governmental actions and factors other than scientific (e.g., political, socio-economic, cultural). What is beyond dispute, however, is that, without adequate monitoring data, there simply is not even the opportunity to try to avert a volcanic catastrophe. A tragic reminder of this sobering reality is the 1982 eruption of El Chichón Volcano (Chiapas State, Mexico), which killed more than 2000 people and caused the worst volcanic disaster in Mexico's recorded history. Before 1982, there were very few basic studies of this volcano and no volcano-monitoring studies of its precursory activity. Thus, the eruption came as a deadly surprise to scientists and officials (Tilling, 2007b). Compared to the potentially very high socio-economic losses from a volcanic catastrophe, the scientific and monetary resources to conduct adequate volcano monitoring at high-risk volcanoes in populated regions are modest by comparison. The paramount challenge for volcanologists as well as emergency-management officials is to prevent a volcanic crisis from turning into a volcanic disaster. 
Acknowledgements. I wish to express my appreciation to the Organizing Committee for inviting me to participate in the Second Alexander von Humboldt International Conference. Sincere thanks go to B. Chouet and D. Venezky (both of the USGS) and an anonymous reviewer for helpful constructive reviews of an earlier version of this paper.

Edited by: P. Fabian

Reviewed by: D. Venezky, B. Chouet, and another anonymous referees

\section{References}

Auger, E., D'Auria, L., Martini, M., Chouet, B., and Dawson, P.: Real-time monitoring and massive inversion of source parameters of very long period seismic signals: An application to Stromboli Volcano, Italy, Geophys. Res. Lett., 33, L04301, doi:10.1029/2005GL024703, 2006.

Banks, N. G., Tilling, R. I., Harlow, D. H., and Ewert, J. W.: Volcano monitoring and short-term forecasts, in: Short Courses in Geology, edited by: Tilling, R. I., Vol. 1, Volcanic hazards, American Geophysical Union, Washington, D.C., Chap. 4, 5180, 1989.

Battaglia, M., Roberts, C., and Segall, P.: The mechanics of unrest at Long Valley caldera, California: 2. Constraining the nature of the source using geodetic and micro-gravity data, J. Volcanol. Geoth. Res., 127, 219-245, 2003.

Berrino, G., Corrado, G., Luongo, G., and Toro, B.: Ground deformation and gravity changes accompanying the 1982 Pozzuoli uplift, B. Volcanol., 47, 187-200, 1984.

Blong, R. and McKee, C.: The Rabaul eruption 1994: Destruction of a town, Natural Hazards Research Centre, Macquarie University, Australia, 52 pp., 1995.

Chouet, B.: Volcano seismology, Pure Appl. Geophys., 160, 3-4, 739-788, 2004

Daag, A. S., Tubianosa, B. S., Newhall, C. G., Tuñgol, N. M., Javier, D., Dolan, M. T., Delos Reyes, P. J., Arboleda, R. A., Martinez, M. L., and Regalado, T. M.: Monitoring sulfur dioxide emission at Mount Pinatubo, in: Fire and Mud: Eruptions and Lahars of Mount Pinatubo, Philippines, edited by: Newhall, C. G. and Punongbayan, R. S., Philippines Institute of Volcanology and Seismology, Quezon City, and University of Washington Press, Seattle, 409-414, 1996.

De Natale, G., Troise, C., and Pingue, F.: A mechanical fluiddynamical model for ground movements at Campi Flegrei caldera, J. Geodyn., 32, 487-517, 2001.

Di Vito, M., Lirer, L., Mastrolorenzo, G., and Rolandi, G.: The 1538 Monte Nuovo eruption (Campi Flegrei, Italy), B. Volcanol., 49, 608-615, 1987.

Dzurisin, D. (Ed.): Volcano deformation: Geodetic Monitoring Techniques, Springer-Praxis, Berlin, Germany, and Chichester, U.K., 441 pp., 2006.

Ewert, J. W., Miller, C. D., Hendley, J. W., and Stauffer, P. H.: Mobile Response Team saves lives in volcanic crises, U.S. Geological Survey Fact Sheet 064-97, 2 pp. (revised June 1998), 1997.

Ewert, J. W., Guffanti, M., and Murray, T. L.: An Assessment of Volcanic Threat and Monitoring Capabilities in the United States: Framework for a National Volcano Early Warning Sys- tem (NVEWS), U.S. Geological Survey Open-File Report 2005 1164, 62 pp., 2005.

Harlow, D. H., Power, J. A., Laguerta, E. P., Ambubuyog, G., White, R. A., and Hoblitt, R. P.: Precursory seismicity and forecasting of the June 15, 1991, eruption of Mount Pinatubo, in: Fire and Mud: Eruptions and Lahars of Mount Pinatubo, Philippines, edited by: Newhall, C. G. and Punongbayan, R. S., Philippines Institute of Volcanology and Seismology, Quezon City, and University of Washington Press, Seattle, 285-305, 1996.

Hill, D. P.: Unrest in Long Valley Caldera, California, 1978-2004, Geological Society of London, Special Publications, 269, 1-24, 2006.

Lipman, P. W. and Mullineaux, D. R. (Eds.): The 1980 eruptions of Mount St. Helens, Washington, U.S. Geological Survey Professional Paper 1250, 844 pp., 1981.

McKee, C. O., Johnson, R. W., Lowenstein, P. L., Riley, S. J., Blong, R. J., de Saint Ours, P., and Talai, B.: Rabaul caldera, Papua New Guinea: volcanic hazards, surveillance, and eruption contingency planning, J. Volcanol. Geoth. Res., 23, 195237, 1985

McNutt, S. R.: Seismic monitoring, in: Encyclopedia of Volcanoes, edited by: Sigurdsson, H., Houghton, B., McNutt, S. R., Rymer, H., and Stix, J., Academic Press, San Diego, California, Chapter 68, 1095-1119, 2000a.

McNutt, S. R.: Synthesis of volcano monitoring, in: Encyclopedia of Volcanoes, edited by: Sigurdsson, H., Houghton, B., McNutt, S. R., Rymer, H., and Stix, J., Academic Press, San Diego, California, Chapter 71, 1167-1185, 2000b.

Mori, J. and C. McKee: Outward-dipping ring-fault structure at Rabaul caldera as shown by earthquake locations, Science, 235 , 193-195, 1987.

Mori, J., McKee, C., Itikarai, I., Lowenstein, P., de Saint Ours, P., and Talai, B.:, Earthquakes of the Rabaul seismo-deformational crisis September 1983 to July 1985: Seismicity on a caldera ring fault, in: IAVCEI Proceedings in Volcanology 1, edited by: Latter, J. H., Volcanic Hazards: Assessment and Monitoring, 429462, 1989.

Murray, T. L., Ewert, J. W., Lockhart, A. B., and LaHusen, R. G.: The Integrated Mobile Volcano-Monitoring System Used by the Volcano Disaster Assistance Program (VDAP), in: Monitoring and mitigation of volcano hazards, edited by: Scarpa, R. and Tilling, R. I., Springer-Verlag, Heidelberg, Germany, 315-362, 1996.

Newhall, C. G. and Punongbayan, R. S. (Eds.): Fire and Mud: Eruptions and Lahars of Mount Pinatubo, Philippines, Philippines Institute of Volcanology and Seismology, Quezon City, and University of Washington Press, Seattle, 1126 pp., 2006.

Osservatorio Vesuviano: Campi Flegrei, Italia, http://www.ov.ingv it/italiano/flegrei/flegrei.htm, accessed: 12 September 2007.

Scarpa, R. and Tilling, R. I.: Monitoring and mitigation of volcano hazards, Springer-Verlag, Heidelberg, Germany, 841 pp., 1996.

Simkin, T. and Siebert, L.: Volcanoes of the World: A Regional Directory, Gazetteer, and Chronology of Volcanism During the Last 10,000 Years (Second Edition), Smithsonian Institution, Washington, D.C., and Geoscience Press, Inc., Tucson, Arizona, 349 pp., 1994

Tilling, R. I.: Volcanic hazards and their mitigation: Progress and problems, Rev. Geophys., 27, 2, 237-269, 1989a.

Tilling, R. I.: Introduction and overview, in: Short Courses in Geol- 
ogy, edited by: Tilling, R. I., Vol. 1, Volcanic hazards, American Geophysical Union, Washington, D.C., Chap. 1, 1-8, 1989b.

Tilling, R. I.: The role of monitoring in forecasting volcanic events, in: Monitoring Active Volcanoes: Strategies, Procedures, and Techniques, Chapter 14, edited by: McGuire, W. J., Kilburn, C. R. J., and Murray, J. B., UCL Press, London, 369-402, 1995.

Tilling, R. I.: Volcano monitoring and eruption warnings, in: Early Warning Systems for Natural Disaster Reduction, edited by: Zschau, J. and Küppers, A. N., Springer-Verlag, Berlin Heidelberg, Chap. 5.15, 505-510, 2003.

Tilling, R. I.: Volcano Hazards, in: Volcanoes and the Environment, edited by: Martí, J. and Ernst, G., Cambridge University Press, Cambridge, U.K., Chap. 2, 56-89, 2005.

Tilling, R. I.: Volcano monitoring in reducing volcano risk: Program and Abstracts, The Role of Geophysics in Natural Disaster Prevention, 2nd Alexander von Humboldt International Conference, Lima, Perú, 5-9 March 2007, p. 17, 2007a.

Tilling, R. I.: El Chichón's “surprise” eruption in 1982: Lessons for reducing volcano risk (Abstract), Abstract Volume, El Chichón Volcano: Twenty-five Years Later - A Commemorative Conference (19-25 March 2007, San Cristóbal de las Casas, Chiapas, Mexico), Publicación Especial 6, Universidad Nacional Autónoma de México, p. 112, 2007b.

Tilling, R. I., Heliker, C., and Wright, T. L.: Eruptions of Hawaiian volcanoes: Past, present, and future, U.S. Geological Survey general-interest publications series, 54 pp., (upated in June 1997) 1987.
Troise, C., De Natale, G., Pingue, F., Obrizzo, F., De Martino, P., Tammaro, U., and Boschi, E.: Renewed ground uplift at Campi Flegrei caldera (Italy): New insight on magmatic processes and forecast, Geophys. Res. Lett., 34, L03301, doi:10.1029/2006GL28545, 2007.

Waite, G. P. and Smith, R. B.: Seismic evidence for fluid migration accompanying subsidence of the Yellowstone caldera, J. Geophys. Res., 107, 2177-2192, 2002.

Waite, G. P., Chouet, B. A., and Dawson, P. B.: Eruption dynamics at Mount St. Helens imaged from inversion of broadband waveforms: interaction of the shallow magmatic and hydrothermal system, J. Geophys. Res., doi:10.1029/2005JB005259, in press, 2007.

White, R.: Precursory deep long-period earthquakes at Mount Pinatubo: Spatio-temporal link to a basalt trigger?, in: Fire and Mud: Eruptions and Lahars of Mount Pinatubo, Philippines, edited by: Newhall, C. G. and Punongbayan, R. S., Philippines Institute of Volcanology and Seismology, Quezon City, and University of Washington Press, Seattle, 307-327, 1996.

Wicks, C., Thatcher, W., Dzurisin, D., and Svarc, J.: Uplift, thermal unrest, and magma intrusion at Yellowstone Caldera, Nature, 440, 72-75, 2006. 